\title{
A Comparative Study of Taking Pride in One's Own Poetry: Hafez and Shakespeare
}

\author{
Roohollah Roozbeh
}

\author{
Department of English Language and Literature, Faculty of Literature and Humanities, \\ Vali-e-Asr University of Rafsanjan, 22 Bahman Square, Rafsanjan, Iran \\ r.roozbeh@vru.ac.ir
}

Keywords: comparative literature, Hafez, Shakespeare, pride

\begin{abstract}
Pride is discredited in all cultures, but pride in poetic talent is praiseworthy in all areas. In poetry, the geniuses of all eras have enjoyed their poetry and have paid attention to and have taken great pride in their own poetry. Hafiz boasts of his poetry and is so sure of his poetry that he knows that so long as people reside on earth, the world will read and receive his poetry. The same parallel is found in Shakespeare's poetry so much so that Shakespeare is sure that his poem will be read so long as people can breathe and see. This belief in the immortality of poetry and its effects in the two poets are followed in this article. The dimensions of this issue and the reasons for the discourse of poetry and sonnet are explained in detail. The conclusion is that the two poets are proud of beautiful form and musicality of their poetry which will spread through the world. This is endorsed through the untranslatability of the poems of the two poets 'poetry. The methodology of this paper is based on the descriptive-analytical approach of the American comparative Literature School. The focus of this study is to compare pride in the poetry of Hafez and Shakespeare.
\end{abstract}

\section{Introduction}

When God created man, the Lord congratulated himself for the creation of human beings. In classical literature, the poet was considered to be the creator of his work [1]. Having composed a beautiful poem, the classical poet congratulated himself. This is abundant in the literature of Iran. Poets who are fond of their own poetry, have praised themselves a lot. Artists, in an institutional and unconscious way, consider themselves superior to others, because they find the great ability of their own, which is not found in others who are not capable of being creative. For this reason, great artists have inevitably been narcissistic [2]. Such a poet was a special person. Shakespeare is the genius of British literature, who is known to everyone. Shakespeare claims that his poetry is immortal and he is proud of his poetry, and in English literature everyone considers him as the glory of English literature that shines on British literature. He is one of the greatest English poets in the field of sonnets and has a special style and ability known to critics. He comprehended the delicacies of English language in depth, and has captured English language's capacity and power in expressing thought in the most artistic way, and by discovering meaning and music in the English language, he exalted his speech and has been proud of it. Shakespeare, knowing that there is a desire for immortality in man, believes in immortality through poetry and maintains human beings will remain eternal in poetry only. Alexander is said to have expressed his envy of Achilles, since Achilles has had someone like Homer to immortalize him in his poetry [3], a poet who praises a hero and makes him immortal in his poem is a great and prominent person himself, and the fame of heroes like Achilles and others depend on him. Since such a poet whose poetry is rich and great, can immortalize and magnify others. Poets are aware of this point and they are proud of their poetry.

Hafez is one of the most prominent Iranian poets in the field of sonnet, who owns a special style and has a unique ability to compose poetry. He has comprehended the delicacy and subtlety of Persian language and understood its capacity and power in expressing thought in an artistic method and, in discovering meaning and music in the words, transcended his speech and has been proud of it. It should be noted that, until the time of Hafez's emergence, the sonnet had become monotonous; Hafez had foregrounded it in the praise of the beloved. 


\subsection{Review of Literature}

In the field of pride in poetry in poets, several articles have been written, including Mohammad Hussein Nikdarasl [4] in his article entitled "The Study of the Pride in the Divan of Hafez" maintains pride is, in fact, a literary genre which is found both in poetry and prose. This genre, in every age, accepts a special colour and cannot be unaffected by the temporal and spatial effects. In his article, he explores the nature of pride and its relationship with the subject of personality and the individual's thinking about himself and his function as a psycho-personality element and has examined Hafez's sonnet which is Hafez's point of pride. He believes that Hafez's greatest pride is in speech and sonnet. He has examined Hafez's pride in great efforts, pride in cleverness, pride in love and beloved, which is rooted in the political and social age of the poet [4].

Khalil Parvini and Touraj Zeynivand [5] in their article entitled "pride in the poetry of Motenabi and Khaghani", have investigated pride comparatively in the poetry of the two Arab poets and the Persian poets Khaghani and Motenabi. Comparing the virtues of these two poets, the writers believe the two poets have dealt with pride on the grounds of the natural, social, political, and cultural conditions, attracting the attention of mourning people, defending oneself in conflict and self-determination, and self-reliance on defeats and degradations. In addition, there are similarities and differences in the form and theme among the proud points. Gholam Reza Kafi, in his article entitled "The Study of prides' Types in the Divan of Talib Amoli", believes that the pride which is considered to be a branch of the epic literary genre is one of the themes of thematic Persian poetry, and of the world literature [6].

Of course, some poets benefit greatly from the genre of pride poetry and Amoli is one of those figures. Talib Amoli has exaggerated himself in self-esteem and superiority with his melancholy and passion for his poetry. Kafi, in this article, has examined various types of pride in more than ten divisions, and has studied the reasons for the poet's pride. Also, speaking of "antifoolishness or fear of felicity" is a new topic which Kafi has considered in his article and in light of its numerous evidence in the poem of Talib Amoli. He believes that speaking and pride in moral virtues are among Amoli's best-known pride points [6]. For the review of literature one can refer to The Book of Pride in the Persian Literature (2004) by Ahmad Amiri Khorasani and Naqshband Sokhan (1990) by Jalil Tajlil, Comparative Criticism of Iranian and Arabic Literature (1985) by Saeed Ziaeddin Sajjadi and Pride book in Rudaki's Poetry by Maryam Mahmoudi, Three Poets by Ali Akbar Farzampour, Self-Esteem and Pride in the Persian Poetry by Seyyed Hasan Amin, and Self-narcisim of Persian Poets to the 8th Century by Hashem Mahmoudi.

\section{Discussion}

\subsection{Hafez's Pride in his poetry}

Hafez is one of the four pillars of Persian literature and poetry, due to his success in sonnets, his fame and songs have gained popularity not only in the land of Fars, but in some parts of the Islamic lands. Mohammad Golegandom, the first collector of Hafez's lyrics, says:

In the meantime, the popularity of his globalized ghazals, for some time, have come to Turkey and India ", and the rhymes of his delightful speech have shortly have reached around the streets of Iraq and Azerbaijan. ... Samah (dance) of the Sufi did not work without his haughty sonnets, and the House of wine drinkers and wine worshipers did not thrive without the tune of his words. [4]

Zarinkoub believes that the period of Hafez's life outside Fars also had prospered, and the kings and the name-seekers had been eager to talk to and visit him [7]. Sultan Oveis Ilkani in the grip of the last days of the rule of Muhtasib attracted the attention of the poet to his court. Sultan Ahmad Ilkani got in touch with him and invited him to Baghdad and Tabriz. Atabak Lor gave him hopes of tips, and King Hormuz was very grateful to him. Even the kings of India and Deccan had corresponded with him [7]. The reason for the correspondence of the kings with Hafez is perhaps the same envy which Alexander had expressed to Achilles. The kings who had correspondence with 
Hafez undoubtedly sought immortality and wanted to have their names remain in his poetry for the future generations, asking him to go to their land and associate with them. Persian poets have immortalized in their poetry many politicians and kings. The position of the poets has led to the globalization of the theme of pride, in which the kings would see poetry as a suitable medium and an appropriate propaganda medium for their own benefits, and would ask a mighty poet to praise them in their poetry and make their virtues noticeable in order to make the society love the kings and win popular support.

\subsection{Globalization of Hafez's poems}

In Hafez's poems, a kind of narcissism is apparent. For example, in the following verse this kind of pride is evident:

Iraq and Persia, you have captured with your poetry/Hafiz, come, now is the turn of Baghdad and the time of Tabriz [8]

Hafez's taking pride in globalization of his poetry in the above lines is quite obvious. Hafiz acknowledges that his poetry is transnational, and it is worth noting that authentic literature will become global. This world of literature is due to the fact that the poet is strong and great, and has reached the highest levels of poetry. Such a claim is worthy of attention because the poet knows that his poetry will sweep the world and go beyond boundaries. This, of course, points out that Hafez pride in the Persian language has spread in the world and has reached the world. It boasts of Iran's power and it can be said that the expansion of poetry is accompanied by the expansion of power. This is a boon to the language, culture and nation of Iran. Somewhere else, Hafez takes great pride in his poetry and claims the saviors of other lands, having heard his lyrics, have fallen in love and his lyrics have inspired the cheerfulness of the beauties. The reputation of Hafez's sonnets spread the whisper of love in other lands:

To the poem of Hafez of Shiraz, the beautiful girls of Kashmiri and Samarghand dance and are proud, [8].

Hafiz once again refers to other lands: Kashmir and Samarkand. Proud claiming is one of the most frequent repercussion of Hafez's poetry. In the above cases, it is time for Kashmir and Samarkand to take refuge in Hafiz's poetry. In the following passages, Hafez refers to Hijaz and Iraq in whose lands his sonnets are read aloud:

The whisper of love in Hejaz and Iraq/Is spread through the sonnets of Hafez of Shiraz [8].

Hafez sees the saga of his sweet sonnets in Egypt, China, and Rome, and maybe this is the culmination of the internationalization of Hafiz's sonnets that are famous and has travelled the world:

Hafez! the enchanting word of yours has reached /Egypt and China, and around Rome and Rey[8].

Hafiz's pride in his poetry is fully deliberate and he considers his being skillful in poetry because of patience: All these nectars and sugars which are spread from my speech is the wage of patience which was given to me from that branch of candy [8]. In the above lines, Hafez consciously uses the two words "nectars" and "sugar" for his poetry which is egotistical and may, at first glance, show Hafez as an arrogant and selfish poet, but in fact, when we go to his poetry and examine his lyrics, we are convinced that this pride and fame are worthy of his poetry because there is no one, like Hafez, whose poem is full of nectar and sugar. Hafez has used sugar to define his poetry. Hafez, for example, uses this term again: seek healing by sugary speech of Hafez, protecting you from the need to treat illness via rose and sugar [8]. What is so proudly in these lines is that Hafez takes pride in his poetry's healing power. Today in the world, the literature therapy is approved, and this aspect of the poetry of Hafiz, which he also boasts of, needs another paper to be addressed. 


\subsection{Shakespeare's Pride in his poetry}

Ben Jonson writes in his poem "To the Memory of My Beloved, The Author, Mr. William Shakespeare, and What He Hath Left Us," in the description of Shakespeare's reputation: "Soul of the age!/The applause! Delight! The wonder of our stage!/My Shakespeare, rise; I will not lodge thee by/Chaucer or Spenser, or bid Beaumont lie/A little further to make thee a room:/Thou art a monument without a tomb,/And art alive still while thy book doth live, And we have wits to read and praise to give "[3] Francis Meres in Paldis Tomia: Treasury Intelligence (1598) states in relation to Shakespeare: "As Platus and Seneca among Latin literature are the best comedians and tragedians respectively, Shakespeare is the best in both comedy and tragedy. " [3] His works have been respected and acclaimed for centuries, and the secret of this pleasure can be found in the selection and consideration of common humanitarian issues. Mojtaba Minovi states that "over four hundred and fifty sentences of his words in English have become proverbs, and besides, nearly two thousand expressions and poems are recited by people. English is associated with Shakespeare's folk songs, and one who wants to know English people very well must know Shakespeare and his compositions "[9]. If Shakespeare has succeeded in describing the West's demands, wishes, interests, horrors, horizons, and the desires of humanity as much as possible in the form of his sonnets so has Hafez in the literature of Iran. John Dryden says about Shakespeare:

To begin, then, with Shakespeare. He was the man who of all modern, and perhaps ancient poets, had the largest and most comprehensive soul. All the images of Nature were still present to him and he drew them, not laboriously, but luckily; when he describes any thing, you more than see it, you feel it too. Those who accuse him to have wanted learning, give him the greater commendation: he was naturally learned; he needed not the spectacles of books to read nature; he looked inwards, and found her there. I cannot say he is everywhere alike; were he so, I should do him injury to compare him with the greatest of mankind. [10]

Shakespeare claims his sonnets will be read till all people are alive. We know that Shakespeare's in his sonnets refers to English-speaking people, not the people of China and others. Shakespeare claims that as long as English speakers speak English, his sonnets will be recalled and read. Surely Shakespeare does not have in mind the whole world, but England and nations that may speak in English, because at Shakespeare's time, only Britain itself spoke English, and English had not yet entered other continents. The following is one of his sonnets:

When I consider everything that grows
Holds in perfection but a little moment,
That this huge stage presenteth nought but shows
Whereon the stars in secret influence comment;
When I perceive that men as plants increase,
Cheered and check'd even by the selfsame sky,
Vaunt in their youthful sap, at height decrease,
And wear their brave state out of memory;
Then the conceit of this inconstant stay
Sets you most rich in youth before my sight,
Where wasteful Time debateth with Decay
To change your day of youth to sullied night;
And all in war with Time for love of you,
As he takes from you, I engraft you new. [11]

In this poem, the poet thinks all living beings will die one day and will only be perfect for a short time, and that the whole world is just a great scene on which the stars control all human actions; and men are like herbs. They grow up and grow, and then they are destroyed by heaven, they are happy with their youthful energy, they die at the height of their youth and disappear, and their glory will go away, and instability will rule over the whole world. The poet's purpose in mentioning these materials is to make a valuable point. The point that the poet emphasizes is immortality. His intention is to immortalize someone. The following is a sonnet that is about a 
young person whom the poet praises and makes eternal. In the poet's opinion time and corruption fight to destroy the brilliant youth of the beloved and make it old and dark. Shakespeare will fight against time for the sake of love for his love. According to the poet, as time struggles to eliminate the beloved's youth, the poet will continuously retrieve the beloved in this eternal lines and rebuild and redeem his life again. In sonnet 18 he again covers the same theme:

Shall I compare thee to a summer's day?

Thou art more lovely and more temperate:

Rough winds do shake the darling buds of May,

And summer's lease hath all too short a date:

Sometime too hot the eye of heaven shines,

And often is his gold complexion dimm'd;

And every fair from fair sometime declines,

By chance, or nature's changing course, untrimm'd;

But thy eternal summer shall not fade

Nor lose possession of that fair thou ow'st;

Nor shall Death brag thou wander'st in his shade,

When in eternal lines to time thou grow'st;

So long as men can breathe or eyes can see,

So long lives this, and this gives life to thee [11].

Shakespeare in this sonnet describes the fleeting nature of spring to pursue a goal. Shakespeare's excuse for this sonnet is clear. If the person in question is a man, as is said by some critics, this will bring the question of homosexuality to the surface. But since there is no document available to identify the personality and gender of the person concerned, one cannot attribute the sonnets to the man Shakespeare was interested in. But that this person is female is more probable because poets have composed so much poetry for their mistresses. But the point that should not be forgotten is that in these sonnets Shakespeare is proud of the immortality of his poetry and can immortalize human being. The point to be considered in this sonnet is the importance of sonnet against mortality. Shakespeare also emphasizes this point and boasts of his poetry's power. In this poem, the poet intends to compare the mistress with summer and spring. The poet knows the spring is transitory, saying that spring cannot be eternal in any way. The poet speaks of all the features of the spring to follow a point. The poet mentions all the beauties of the spring: he speaks of spring flowers. What is noteworthy is that it considers all spring flowers and all spring trees to be fleeting, and says that all of this will be destroyed one day. But my poetry will last forever. If you want to be eternal, such immortality is in my poem. It is a boon to poetry. Poetry can be more beautiful and immortal than the beauty of spring. This thought is also found in Sa'di's poem, where he says, "take a sheet from my Golestan. The flower lasts for five or six days. This Golestan is always permanent."[12] He set his poetry against nature: nature is mortal and transient, but poetry is eternal and everlasting. This is a big claim on the part of the poet and says that his poetry is eternal. The cute poet reaches the climax of taking great pride in his poetry when he tells the beloved that death cannot bluff you walk under its shade because you live in the immortal realm of my poetry. The phrase "eternal verses" in sonnet 12 expresses the poet's favour of his poetry that is immortal and time has no effect on the poet's eternal poetry, and cannot put his poetry into an abyss. Immortality will be in harmony only with poetry. The beloved will see no deterioration, and no aging when portrayed in poetry. This is also mentioned in sonnet 19:

Devouring Time, blunt thou the lion's paws, And make the earth devour her own sweet brood; Pluck the keen teeth from the fierce tiger's jaws, And burn the long-lived phoenix in her blood; Make glad and sorry seasons as thou fleet'st, And do whate'er thou wilt, swift-footed Time, To the wide world and all her fading sweets; 
But I forbid thee one most heinous crime:

O, carve not with thy hours my love's fair brow,

Nor draw no lines there with thine antique pen;

Him in thy course untainted do allow

For beauty's pattern to succeeding men.

Yet, do thy worst, old Time: despite thy wrong,

My love shall in my verse ever live young. [11]

In this context Shakespeare criticizes time. World devouring time blunts the paws of the lion. It causes the earth to swallow plants. It brings out the sharp teeth of the violent tiger out of its jaw and burns the Phoenix in its blood. As it moves forward, it make some happy and some sad and does whatever he wants to do. The poet has an answer to the troubles of the time in his sleeve and that is his poetry. Shakespeare, with his fame, sets his poetry against time, telling time that poetry will stand against it and will make the beloved immortal. The poet's poetry will not allow the old age the dream of creating wrinkles on the beautiful forehead of the beloved of the poet. In sonnet 55 Shakespeare take great pride in his poetry:

Not marble nor the gilded monuments

Of princes shall outlive this powerful rhyme,

But you shall shine more bright in these contents

Than unswept stone besmeared with sluttish time.

When wasteful war shall statues overturn,

And broils root out the work of masonry,

Nor Mars his sword nor war's quick fire shall burn

The living record of your memory.

'Gainst death and all-oblivious enmity

Shall you pace forth; your praise shall still find room

Even in the eyes of all posterity

That wear this world out to the ending doom.

So, till the Judgement that yourself arise,

You live in this, and dwell in lovers' eyes. [11]

In this poem, the poet continues to take pride in his poetry. In this poem, the author points out that his poetry is immortal and compares it to monuments, and believes that poetry is better than monuments, in other words, it can be superior to history, and will be more permanent than all palaces of gold and marble. Strong poetry and lyricism gives the beloved eternal life. The poet says that the beloved will shine more in his poem. He believes that all the future will be informed about you when I talk about you in my poetry. Your beautiful memory will be immortal against all enmities of nature.

What is noteworthy is that the poet in his own unconscious views himself because there is no name of his friend in his poems and nor a history of this person. So a friend who does not have a name and does not have any history, cannot be anybody but the poet himself, who expresses himself behind a friend. Jane Hedley also believes that the poet is more in love with the psychological projection that equals the ideal image of what Freud called "self-ideal" [13] (Hadley, 1994: 2). Thus, what is meant by procreation in poetry can be the reproduction of the author's own poetry. Of course, if we look at Shakespeare's poetry and lyricism from the formalist point of view, we can see that the meaning of a friend can be beloved, but since the mother of the person who belongs to the aristocracy has asked Shakespeare to compose sonnets to encourage her son to marry and produce an heir to continue his superior and superior generation, one can say Shakespeare has British race and its production in mind. Of the 154 Shakespearean sonnet, 126 sonnets refer to this theme. This is the number of Shakespeare's sonnets about marriage and encouraging young people to marry. It can be said Shakespeare has in mind the eternal survival of Britain's superior race, a race that considers itself superior and more beautiful than other nations. Shakespeare considers himself superior and therefore wants to promote the superiority of England in his poetry and push the young into marriage and production of a beautiful race. 


\section{Conclusion}

Taking great pride in one's own poetry is one of the preeminent themes in the poetry of Hafez and Shakespeare. A large number of Shakespeare's sonnets point to marriage and procreation. This number of Shakespeare's sonnets is meaningful in this regard. It can be said Shakespeare, in fact, copes with the eternal survival of Britain's superior race, a race that considers itself superior and more beautiful than other races. Shakespeare considers himself superior and therefore wants to promote the superiority of England in his poetry and encourage young British people to get married and produce an attractive race. Taking great pride in one's poetry is accompanied with a kind of exaggeration in both poets. Shakespeare's poetry is an eternal one, and Shakespeare is proud of his poetry. The same is true of Hafiz's poetry. This honour is more indicative of the greatness and prestige of the two poets in the literature of their countries. The poetry of these two poets was not confined to their borders and transcended the geographical borders. The poets are so sure of themselves that they know that until people live, their poetry will be eternal, and will read throughout the course of time. Hafez also refers to the names of countries that read Hafez's poetry, including those of Iraq and Egypt. But Shakespeare does not mention the name of any country. Of course, both in Hafez and Shakespeare, it is possible to point out that their poems have become more or less, common in countries that speak the language of the poet, that is to say in Persian speaking world and in English speaking world. Of course, it should be noted that Hafez refers to Samarkand, Iraq and China. Because China did not speak Persian at the time of Hafez, why is Hafez talking about China? Does Hafez mean that his poetry will be translated and made world-wide? Hafez's pride is greater than Shakespeare to internationalize and become popular in his poetry. Hafez refers to China, Iraq and Egypt. How can the poetry of Hafez capture these countries when they have their own languages and do not speak Persian? Is Hafez confident that his poems will be translated into other languages? Surely, the latter cannot be right, because the translation of Hafez's poetry into the language of these countries will lose its beauty and will not have a pleasant and beautiful form. His poems are beautiful and eternal in his own language. If Hafez's poems are translated into Arabic or Chinese, there will be no language and form. It may be thought that Hafez's thought is to be translated. But this is also not verifiable because Hafiz claims that "to the poetry of Hafez Shiraz dance / the beautiful girls of Kashmir and Samarghand, so what is meant is the language or the beautiful form not the idea.

\section{References}

[1] V. Hall, A short history of literary criticism, New York University Press, 1963.

[2] Mir Jalaloddin Kazazi, "Self-incomprehensibility" of the journal of the Faculty of Literature and "Self-Definition", Journal of Humanities of Ferdowsi University of Mashhad. 35(1-2) (2002) 75-82.

[3] M.H. Abrams, Norton Anthology of English Literature. 4th edition, Norton Company Press, New York, 2004.

[4] N.M. Hossein, A Study of pride species in the Hafez poetry, Poetry Research (Bostan Adab Social Sciences and Humanities). 2(3) (2010) 223-248.

[5] K. Parvini, Z.V. Touraj, Fakhr in Textbook and Khaghani Poetry, Journal of Folklore and Literature, Faculty of Literatures \& Humanities of Mashhad. 37(2) (2004) 155-173.

[6] G. Kafi, A Study of Pride Types in the Amoli Divan, Poetry Research (Bostan Adab - Social Sciences and Humanities). 5(2) (2013) 103-130.

[7] A.H. Zarinkoub, Az Kouche Rendaan, Amir Kabir, Tehran, Iran, 2006.

[8] S.M. Hafez, The Divan of Mohammad Ghazvini and Qasem Ghani, Introduction by Mohammad Glendam, Asma, Tehran, 2005.

[9] M. Minovi, Fifteen speeches, Third Edition, Toos Publication, Tehran, Iran, 1988. 
[10] J. Dryden, R. Howard. Dryden \& Howard, 1664-1668: The Text of an Essay of Dramatic Poesy, the Indian Emperor and The Duke of Lerma, with Other Controversial Matter. CUP Archive, 1929.

[11] William Shakespeare, The complete sonnets and poems, Oxford University Press on Demand, 2002.

[12] Saadi Shirazi, Golestan. Corrected by the late Foroughi, Hermes Publishers, Tehran, Iran

[13] J. Hedley, Since First Your Eye I Eyed: Shakespeare's "Sonnets" and the Poetics of Narcissism, Style. 28(1) (1994) 1-30. 